\title{
Qu-2, a robust poplar suspension cell line for molecular biology
}

\author{
Caixia Liu ${ }^{1} \cdot{\text { Kailong } \mathrm{Li}^{1} \cdot \text { Meng Wang }}^{1} \cdot$ Erqin Fan ${ }^{1,2} \cdot$ Chuanping Yang ${ }^{1}$ \\ Junhui Wang ${ }^{2} \cdot$ Pengyue Fu ${ }^{1} \cdot$ Xiaolan $\mathrm{Ge}^{1} \cdot$ Heike W. Sederoff ${ }^{3}$. \\ Ronald R. Sederoff ${ }^{1,4} \cdot$ Vincent L. Chiang $^{1,4} \cdot$ Sui Wang ${ }^{1,5} \cdot$ Guanzheng $\mathbf{Q u}^{1}$
}

Received: 21 August 2020 / Accepted: 20 October 2020 / Published online: 6 December 2020

(C) The Author(s) 2020

\begin{abstract}
Populus spp. have long been used as model woody plant species for molecular biology research. However, tissues of poplar are often recalcitrant to experimental procedures for molecular studies. We generated a hormone autotrophic poplar suspension cell line from a hybrid of Populus alba $\times$ P. berolinensis 'Yinzhong', named Qu-2. Qu-2 cells are suitable as a model biological system for studying woody plants. Qu-2 cells have many advantages over suspension cell lines derived so far from any other woody plants. Qu-2 cells are very easy to cultivate and can grow on several common plant culture media without the addition of any plant hormone. They show exceptionally high growth rates, reaching an approximately 150 -fold increase
\end{abstract}

Caixia Liu, Kailong Li and Meng Wang have contributed equally to this work.

Project funding: This research was supported by the National Key Research and Development Program of China (2016YFD0600106), the National Natural Science Foundation of China (31670675) and the Fundamental Research Funds for the Central Universities (2572018CL01 and 2572018CL02).

The online version is available at http://www.springerlink.com.

Corresponding editor: Yu Lei.

Supplementary Information The online version of this article (https://doi.org/10.1007/s11676-020-01266-9) contains supplementary material, which is available to authorized users.

Sui Wang

wangsui.ws@163.com

Guanzheng Qu

gzqu@nefu.edu.cn

1 State Key Laboratory of Tree Genetics and Breeding, Northeast Forestry University, Harbin 150040,

People's Republic of China in biomass after one week of culturing. Another important unique characteristic of Qu-2 cells is that they can be cryopreserved and readily reactivated. Qu-2 cells are suitable for molecular manipulations such as protoplast production, transient transformation, and RNA-seq analysis. Therefore, $\mathrm{Qu}-2$ cells have the great potential to be an excellent model cell line in tree molecular biological research, ranging from physiology to gene function. The Qu-2 cells will be made available to the plant community for research.

Keywords Qu-2 cell line · Suspension cell · Poplar · Protoplast isolation · Transient transformation

\section{Introduction}

Suspension cell lines are useful materials for biological research. HeLa cells, considered an immortal cell line, can be maintained in continuous serial culture (Scherer et al. 1953), offering an enormous help in advancing human medical and biological research. Plant suspension cell lines are widely used in physiology, cytology, biochemistry, developmental biology, genetics, and molecular biology research because of their favorable dispersibility, rapid growth, good repeatability, and ease of manipulation. The BY-2 (Bright Yellow 2) cells derived from Nicotiana tabacum L. are an excellent plant suspension cell line because they grow fast

2 State Key Laboratory of Tree Genetics and Breeding, Key Laboratory of Tree Breeding and Cultivation of State Forestry Administration, Research Institute of Forestry, Chinese Academy of Forestry, Beijing 100091, People's Republic of China

3 Department of Plant and Microbial Biology, North Carolina State University, Raleigh, NC 27695, USA 
and have unique characteristics (Nagata et al. 1992, 2004). BY-2 has been used in many studies, such as cell cycle (Yu et al. 2006; Harashima et al. 2007; Delporte et al. 2014), cell metabolism (Krystofova et al. 2013; Han et al. 2014; Issawi et al. 2017), abiotic stress responses (Banu et al. 2009; Gai et al. 2011) and gene function verification (Han et al. 2014; Niczyj et al. 2016; Toussaint et al. 2017). In addition to BY-2, suspension cell lines have been generated from other plant species, such as thistle (Lattanzio et al. 2018), switch grass (Rao et al. 2017), and rice (Ozawa and Komamine 1989).

Populus is a genus native to most of the Northern Hemisphere. Populus trichocarpa is the first tree species being sequenced for its genome in 2006 (Tuskan et al. 2006) and has been used as a model tree species for molecular genetic research. Although genome sequences of Populus and other forest tree species are available, functional and genetic studies of these species at the whole tree level have always been very difficult. Cell cultures may be alternative systems for these studies. However, the generation of specific tree cell or tissue cultures as biological systems for molecular and genetic studies has also been difficult or impossible due to the recalcitrance of woody plant tissues to experimental procedures. Efficient and easy to manipulate suspension cell lines from a tree species, particularly Populus, have been highly desirable for the advancement in forest tree research. Several Populus suspension cell lines have been reported (Bae et al. 2012; Ohlsson et al. 2006; Ohmiya et al. 1995; Park and Son 1988). However, they are not easy to generate and are not designed for yield and quality adequate for a variety of studies. What is also lacking in many of these cell line systems is well-developed cell cryopreservation and reactivation procedures to allow for a continual source of genetically uniform material.

We have developed a unique suspension cell line derived from 'Yinzhong', a hybrid poplar ( $P$. alba $\times$ P. berolinensis $)$, which we named $\mathrm{Qu}-2$. The $\mathrm{Qu}-2$ cells have been cultured, cryopreserved, reactivated and used since 2014 and shown very stable genetic characteristics. Here, we describe the generation and maintenance of the $\mathrm{Qu}-2$ cells and some of their key characteristics required as a model system for plant biological research, especially for tree species.

4 Forest Biotechnology Group, Department of Forestry and Environmental Resources, North Carolina State University, Raleigh, NC 27695, USA

5 Key Laboratory of Soybean Biology in Chinese Ministry of Education, Northeast Agricultural University, Harbin 150030, People's Republic of China

\section{Materials and methods}

\section{Plant materials}

Populus alba $\times$ P. berolinensis 'Yinzhong' is a male triploid hybrid. The 20-year-old donor 'Yinzhong' tree we used is from campus of Northeast Forestry University. Leaf, bud and anther tissues were collected as explants for callus induction.

\section{Acquisition of suspension cell lines derived from callus}

Sterilized explants were transferred to MS medium (Murashige and Skoog 1962) + $2.0 \mathrm{mg} / \mathrm{L}$ 2,4-Dichlorophenoxyacetic acid (2,4-D) $+0.5 \mathrm{mg} / \mathrm{L}$ Kinetin $(\mathrm{KT})+30 \mathrm{~g} / \mathrm{L}$ Sucrose $+3 \mathrm{~g} / \mathrm{L}$ Gelrite. After culturing in dark for about 30 days, the callus was formed. Of the calli derived from the selected explant types, we found that the callus from anthers had loose texture, vigorous growth and bright yellow color, which met the requirements of suspension materials. We then focused on the anther callus for the generation of the suspension cells.

\section{Growth of Qu-2 cells and measurement of the growth rate}

More than 1000 anther callus lines were selected for the generation of the Qu-2 suspension cells and growth measurement of these cell lines. The growth and development of the Qu-2 cells, with and without the presence of plant hormone, was measured every 2 days. For each cell line, $\sim 1.5 \mathrm{~g}$ callus was split into small portions and transferred to hormone-containing liquid medium (MS $+0.15 \mathrm{mg} / \mathrm{L} 2$, 4-D + $0.02 \mathrm{mg} / \mathrm{L} \mathrm{KT}+50 \mathrm{~g} / \mathrm{L}$ Sucrose) and small portions of another $\sim 1.5 \mathrm{~g}$ callus were transferred to hormone-free liquid medium (MS $+50 \mathrm{~g} / \mathrm{L}$ Sucrose) and cultured at $26^{\circ} \mathrm{C}$ with continuous shaking at $110 \mathrm{rpm}$. While culturing, $1 \mathrm{~mL}$ of the suspension cells were taken every 2 days, and the number of cells per unit volume was counted using a hemocytometer.

\section{Cryopreservation and reactivation of the $\mathrm{Qu}-2$ suspension cells}

The suspended Qu-2 cells for $6 \mathrm{~d}$ in the growth phase were added to a suspension medium containing 0.33 or $0.5 \mathrm{~mol} \mathrm{~L}^{-1}$ mannitol for dehydration treatment. After culturing at $26{ }^{\circ} \mathrm{C}$ and $110 \mathrm{rpm}$ for $2 \mathrm{~d}$, the supernatant was removed by low-speed centrifugation $(500 \times g, 5 \mathrm{~min})$ and re-suspended in a suspension medium containing $10 \%(v / v)$ dimethyl sulfoxide (DMSO). It was then transferred to a $2 \mathrm{~mL}$ freezing tube and frozen with stepwise low temperature treatments, $4{ }^{\circ} \mathrm{C}$ for $1 \mathrm{~h},-20{ }^{\circ} \mathrm{C}$ for $2 \mathrm{~h}$, and $-80{ }^{\circ} \mathrm{C}$ overnight, and finally transferred to liquid nitrogen for long-term preservation. To recover cells after one month, 
the suspended cells were removed from liquid nitrogen and immediately placed in a $37{ }^{\circ} \mathrm{C}$ water bath, thawed, washed for 3-4 times with suspension medium containing $10 \%(\mathrm{v} / \mathrm{v})$ DMSO, and transferred to suspension medium with or without plant hormones as described above for cultivation. After $7 \mathrm{~d}, 1 \mathrm{~mL}$ of suspended cells was put into a $10 \mathrm{~mL}$ centrifuge tube containing $0.4 \%(w / v)$ 2,3,5-triphenyl-tetrazolium chloride (TTC), incubated overnight at $37{ }^{\circ} \mathrm{C}$ followed by centrifugation $(500 \times g, 5 \mathrm{~min})$. At last, the cells were resuspended with $3 \mathrm{~mL}$ DMSO, and the absorbance at $\mathrm{OD}_{485}$ was measured to determine the activity.

\section{Plant regeneration from $\mathrm{Qu}-2$ cells}

The vigorously growing Qu-2 callus was placed in MS medium with the addition of three different types of hormones: (1) $0.2 \mathrm{mg} / \mathrm{L}$ 1-Naphthaleneacetic acid (NAA), (2) $0.05 \mathrm{mg} / \mathrm{L}$ Thidiazuron (TDZ) and (3) $0.2 \mathrm{mg} / \mathrm{L}$ $\mathrm{NAA}+1 \mathrm{mg} / \mathrm{L}$ 6-Benzylaminopurine (6-BA) $+0.05 \mathrm{mg} / \mathrm{L}$ TDZ. The callus was then cultured in a tissue culture room (temperature $24-26^{\circ} \mathrm{C}$, light intensity $1000-1500 \mathrm{Lx}$, light/ dark period $16 \mathrm{~h} / 8 \mathrm{~h}$ ) and subcultured every 25 to $30 \mathrm{~d}$ for callus, and whole shoot regenerations.

\section{Protoplast isolation and transformation of $\mathrm{Qu}-2$ cells}

The protoplasts were obtained from Qu-2 cells by enzymatic hydrolysis of the cell wall. The solutions and reagents used for protoplast isolation and genetic transformation are list below. The cell wall digestion enzyme solution: $3 \%(w / v)$ CELLLULASE-R10 (Yakult Pharmaceutical Industry Co., Ltd.), $0.8 \%(w / v)$ MACEROZYME-R10 (Yakult Pharmaceutical Industry Co., Ltd.) in $20 \mathrm{mM} 4$-morpholineethanesulfonic acid (MES), 0.5 M mannitol and $20 \mathrm{mM}$ potassium chloride $(\mathrm{KCl})$. This mixture was incubated at $55^{\circ} \mathrm{C}$ for $10 \mathrm{~min}$ and after being cooled down to room temperature, $10 \mathrm{mM}$ calcium chloride dihydrate $\left(\mathrm{CaCl}_{2} \cdot 2 \mathrm{H}_{2} \mathrm{O}\right)$ and $0.1 \%$ $(w / v)$ bovine serum albumin (BSA) were added. MMG solution: $0.5 \mathrm{M}$ mannitol, $4 \mathrm{mM}$ MES and $15 \mathrm{mM}$ magnesium chloride hexahydrate $\left(\mathrm{MgCl}_{2} \cdot 6 \mathrm{H}_{2} \mathrm{O}\right)$. WI solution: $0.5 \mathrm{M}$ mannitol, $4 \mathrm{mM}$ MES and $20 \mathrm{mM} \mathrm{KCl}$. PEG solution: $0.5 \mathrm{M}$ mannitol, $100 \mathrm{mM} \mathrm{CaCl} \cdot 2 \mathrm{H}_{2} \mathrm{O}$ and $40 \%$ ( $\left.w / v\right)$ PEG4000.

About 3-4 g Qu-2 cells were added into $50 \mathrm{~mL}$ enzyme solution and put on a horizontal shaker for $1.5-2 \mathrm{~h}$. The enzymatic solution was filtered out by qualitative filter paper. The precipitation (cell line after enzymatic hydrolysis) was suspended gently by MMG, the protoplasts were collected through $70 \mu \mathrm{m}$ nylon membrane. The quantity and quality of protoplasts obtained were detected by using blood cell counting plate. PEG-mediated transformation was used. The protoplasts of $100 \mu \mathrm{L}$ were added into $10 \mu \mathrm{L}$ target plasmid and $110 \mu \mathrm{L}$ PEG transformation solution. It was mixed gently and reacted at room temperature for 5-8 $\mathrm{min}$.
The protoplasts were collected by low-speed centrifugation $(400 \times g, 3 \mathrm{~min})$, re-suspended with $1 \mathrm{~mL}$ of WI and transferred to a six-well plate to complete protoplast transformation. The pUC19 vector encoding a green fluorescent protein (sGFP) was used for transient transformation (Lin et al. 2014). Bimolecular Fluorescence Complementation (BiFC) was performed with $\mathrm{Qu}-2$ protoplasts to verify the protein interaction between CbuSPL9 and CbuHMGA, which are proteins related to flower development in Catalpa bungei and known to interact with each other (Wang et al. 2020). The transformation efficiency was estimated using Zeiss LSM700 laser-scanning microscopy.

\section{Agrobacterium tumefaciens-mediated transient transformation of $\mathrm{Qu}-2$ cells}

Agrobacterium was used to transiently transform the $\mathrm{Qu}-2$ cells. The pBI121 vector carrying the GUS gene was used as a plasmid for the transformation. A. tumefaciens strain GV3101 was shaken to activate to the absorbance at $\mathrm{OD}_{600}$ to $0.2-0.3$, and then to the culture $40 \mu \mathrm{M}$ acetosyringone (AS), $0.0002 \mathrm{mg} / \mathrm{L} \mathrm{TDZ}$, and $20 \mathrm{~mL}$ of sterile water were added. Approximately $5 \mathrm{~g}$ of $\mathrm{Qu}-2$ cells were added to the transformation solution, which was held in the dark at $26^{\circ} \mathrm{C}$, and rotated at $110 \mathrm{rpm}$, for 2-3 d. For GUS detection, the $\mathrm{Qu}-2$ cells were collected on qualitative filter paper, transferred to fresh medium, pipetted into a detection solution containing 5-bromo-4-chloro-3-indolyl- $\beta$-D-glucuronic (X-Gluc) (Jefferson et al. 1986), and incubated at $37{ }^{\circ} \mathrm{C}$ overnight. The cells were fixed (Carnoy's fixative) the next day, and the transformation results were quantified.

\section{Full transcriptome analysis of Qu-2 cells by RNA-Seq}

An RNA-Seq experiment with two biological replicates was conducted to compare gene expression patterns of Qu-2 cells with different tissues of $P$. trichocarpa. After dark culture for $6 \mathrm{~d}$, the total RNA was extracted using an Extract kit (RP3301, BioTeke, China). RNA-Seq libraries (PE150) were prepared and sequenced on the MGISEQ-2000 platform (Beijing Genomics Institute, Shenzhen, China) at BGIWuhan (BGI, Wuhan, China). In addition, other RNA-Seq data from different tissues of $P$. trichocarpa were downloaded from NCBI SRA (Sequence Read Archive) database (shoot: SRR3472992, SRR3472993; leaf: SRR3472995, SRR3472996; root: SRR3473000, SRR3473001; xylem: SRR3473003, SRR3473005; phloem: SRR3472997, SRR3472998; fiber: SRR3473006, SRR3473008; vessel: SRR3473010, SRR3473011) (Shi et al. 2017; Chen et al. 2019). Raw data were processed by fastp (v0.19.7) for adapter removal and low-quality read filtering. The qualities of the clean reads were checked using FastQC (v0.11.8). The P. trichocarpa annotated with gene set (v3.0) was 
downloaded from the Phytozome version 12 . We used the kallisto (v0.46.0) (Bray et al. 2016) to calculate gene expression levels and calculated Pearson correlation between Qu-2 cell line protoplasts and other samples.

\section{Results}

\section{Acquisition of Qu-2 suspension cell lines}

We aimed to obtain a suspension cell line of woody species that can be used for molecular biology research. P. alba $\times P$. berolinensis 'Yinzhong' was used to obtain callus from different tissues for suspension cell induction. We found that the calli from anthers were much looser and softer than those from other tissues and were suitable for suspension cell induction (Fig. 1a, b). We generated thousands of callus clones from the anther culture, and those lines with vigorous growth and soft texture were selected for suspension cell induction (Fig. 1c). The small pieces of callus were cultured in a $150 \mathrm{~mL}$ flask containing $50 \mathrm{~mL}$ culture medium through continuous shaking. We observed on a daily basis the growth status of each clone under microscope and selected the fastest growing suspension line. After several rounds of selections, we obtained an expectant suspension cell line and named it Qu-2 (Fig. 1d).
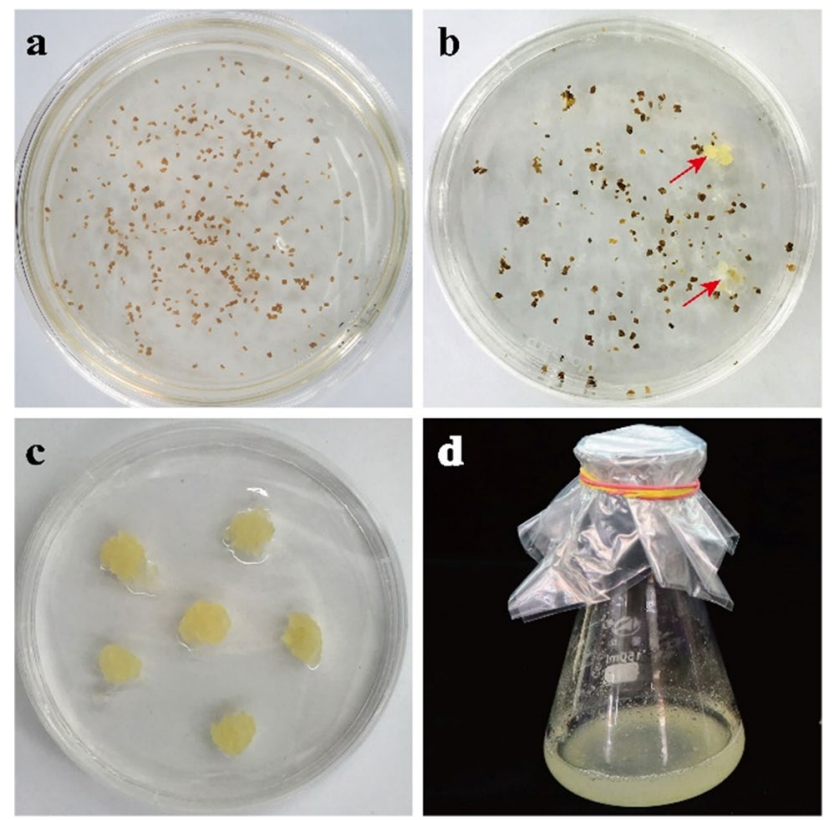

Fig. 1 Acquisition of Qu-2 suspension cell line from poplar anther. a Callus induction was performed on anther derived from 'Yinzhong'; b Obtained poplar anther-induced calli. Arrows show the calli; c The callus grows vigorously and has a soft texture; d Obtained Qu-2 suspension cell line with good dispersion and vigorous growth
Qu-2 cells can be cultured in liquid culture medium with good dispersibility. We observed the growing status of $\mathrm{Qu}-2$ using microscope and found that the Qu-2 suspension cells are present mostly as individual cells or chains of a few cells as they grew (Fig. 2a). In addition, we found that the growth of Qu-2 was hormone-independent. To be more quantitative about the growth, the same amount of callus was tested by culturing in a $150 \mathrm{~mL}$ flask with or without hormones. After one week, the cell numbers in hormone-containing and hormone-free media increased 167 and 135 times compared to the cell numbers at the onset of subcultivation, respectively (Fig. 2b), demonstrating that the Qu-2 cell line exhibits very vigorous growth and hormonal autotrophy. To our best knowledge, the growth rate observed after one week culturing (with or without the presence of hormones) is the highest ever being reported for plant suspension cells so far. In fact, the growth of Qu- 2 cells could not be stopped until the consistency of the culture medium became too high to prevent cell shaking in an orbital incubator (Fig. 2c, d and Electronic Supplemental Video S1). Qu-2 cells are well adapted in such plant tissue culture media, including MS, WPM, B5 and MH.

Cryopreservation is a common method for cell line conservation. We next investigated whether Qu-2 can be cryopreserved. We went through a series of treatments, including dehydration, and gradual cooling to liquid nitrogen. After 1-month cryopreservation, Qu-2 cells were reactivated and tested positive for activity using TTC (Fig. 2e). Therefore, our Qu-2 cell line system includes an effective cryopreservation and reactivation procedure, making this high yield system more robust and useful. Qu-2 cells after 2-year cryopreservation have been successfully recovered in our lab.

\section{Organogenesis of $\mathrm{Qu}-2$ cells}

We also tested whether the Qu-2 cell line can be induced to regenerate plants. Actively growing $\mathrm{Qu}-2$ cells were seeded on induction medium, and after being cultured under light for one month, the cells developed into hardened green callus (Fig. 3a). After three months, buds were formed from the callus followed by shoot elongation (Fig. 3b), and finally, whole shoots were regenerated (Fig. 3c). Our results also show Qu-2 cells were hexaploid confirmed by flow cytometry test (Data not shown), suggesting the genome doubling shows no effect on cell totipotency of Qu-2 cells.

\section{Transient gene expression in Qu-2 cells}

To investigate the feasibility of Qu-2 suspension cells for molecular biology studies, we used Qu-2 cells to perform transient gene expression and BiFC. Transient genetic transformation of suspension cells or protoplasts is widely used to test for gene expression in plants because of the 
Fig. 2 Growth characteristics of hormone autotrophic Qu-2 suspension cell line. a Microscopic observation of cell morphology of Qu-2 cells. Bars $=50 \mu \mathrm{m}$; b Differences in cell number per unit volume of Qu-2 cells when cultured with or without hormones; c Suspension culture of the Qu-2 cells after 17-d culturing with hormones; d Suspension culture of the Qu-2 cells after 17-d culturing without hormone; e The cryopreserved $\mathrm{Qu}-2$ suspension cell line was restored and tested for activity using TTC. (1) the $\mathrm{Qu}-2$ cells restored after cryopreservation; (2) the Qu-2 cells under normal culture conditions
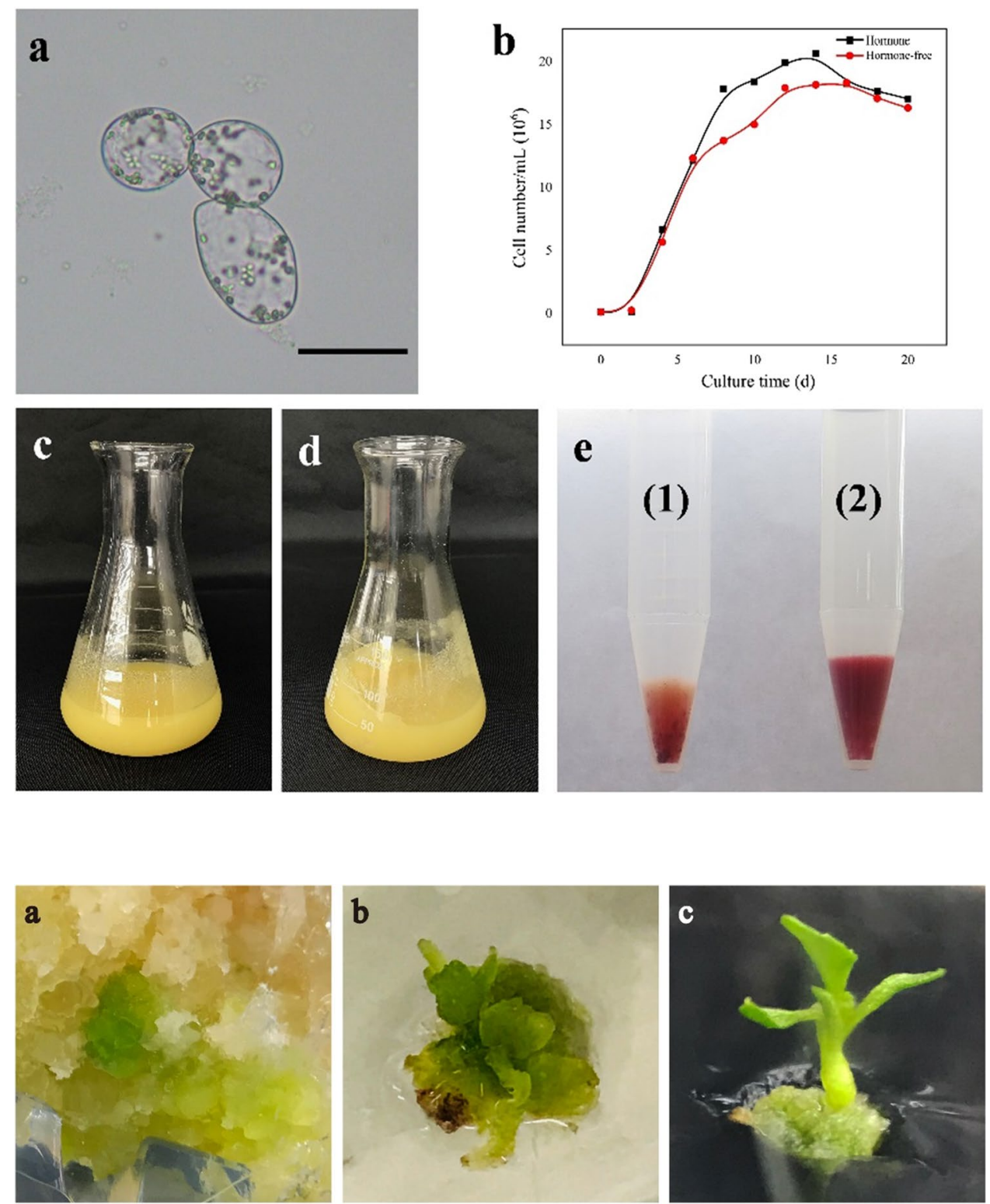

Fig. 3 Plant regeneration from the Qu-2 cells. a Callus developed in one month; b Bud formation and shoot elongation in three months; $\mathbf{c}$ A complete shoot was regenerated from the Qu-2 cells after 3-month culture efficiency, simplicity and short duration of the experiments. Such transformation is particularly useful for the recalcitrant woody plants. The $\mathrm{Qu}-2$ cell line is suitable for both PEG-mediated and A. tumefaciens-mediated transient transformation. Protoplasts isolated from the Qu-2 cells were tested for PEG-mediated transient transformation using pUC19 vector with fluorescent protein (sGFP) driven by a CaMV 35S promoter. The sGFP was successfully expressed in Qu-2 cell protoplasts (Fig. 4a), with transformation efficiencies of about $10-15 \%$. We determined whether $\mathrm{Qu}-2$ cells are suitable for BiFC assays. We tested and validated protein-protein interactions between CbuSPL9 and CbuHMGA (Wang et al. 2020). CbuSPL9:YFPc ${ }^{\mathrm{c}}$, where CbuSPL9 was fused to the
C-terminus of YFP, and CbuHMGA: $\mathrm{YFP}^{\mathrm{N}}$, where CbuHMGA was fused to the N-terminus of YFP, were coexpressed together with the H2A-1:mCherry nuclear marker in $\mathrm{Qu}-2$ protoplasts. The presence of the two fusion protein reconstituted YFP signals, which were colocalized with H2A-1:mCherry exclusively in the nucleus (Fig. 4b). This result was consistent with the previous study (Wang et al. 2020), and indicated that the Qu-2 cell line can be used as a system for BiFC experiments. For A. tumefaciensmediated transient transformation, $\mathrm{Qu}-2$ cells were co-cultured with Agrobacterium (GV3101) harboring pBI121 for 2-3 d, followed by GUS activity assay showing positive transgene expression (Fig. 4c). 

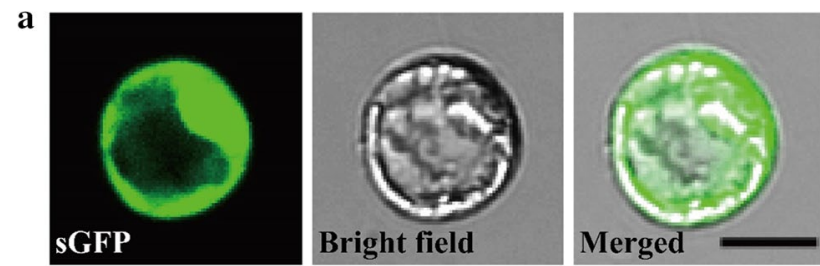

b
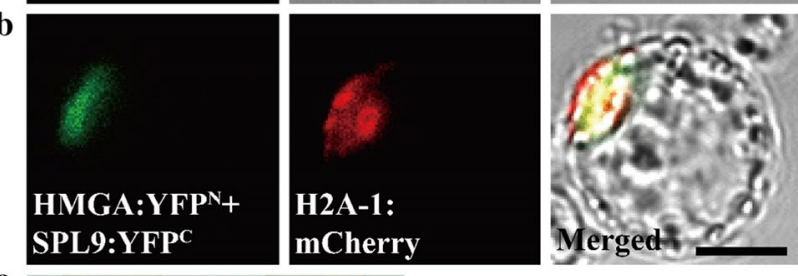

c

(1)

(2)

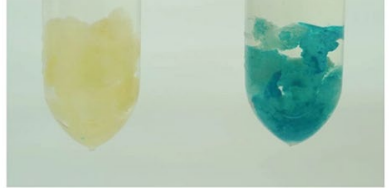

Fig. 4 Transient transformation of Qu-2 cells. a The sGFP-tagged vector was used to transform protoplasts from the $\mathrm{Qu}-2$ cells. Green indicates sGFP signal in Qu-2 cells. Bars $=10 \mu \mathrm{m}$; b BiFC experiments using protoplasts from the Qu-2 cells showed that CbuSPL9 and CbuHMGA proteins interact in the nucleus. Green shows the YFP signals from protein interaction, red indicates the nuclear marker H2A-1:mCherry, and yellow represents the merged signals from YFP and mCherry. Bars $=10 \mu \mathrm{m}$; $\mathbf{c}$ GUS staining of Qu-2 cells after transient transformation by Agrobacterium. (1) the Qu-2 cells; (2) the $\mathrm{Qu}-2$ cells treated with transient transformation

\section{Analysis of gene expression patterns}

Gene expression patterns are not homogeneous across different tissues and even different cell types of a particular organ. Different gene expression patterns determine the identity of each cells. Here, we used correlation analysis to roughly analyze the gene expression patterns of different samples. For two biological replicates of RNA-seq analyses of Qu-2 cells generated approximately 27.6 million and 28.9 million paired-end $150 \mathrm{bp}$ raw reads, where approximately 25.9 million and 27.1 million 130 bp clean reads were obtained, respectively. We also used a similar strategy (Beyrne et al. 2019) to filter RNA-seq data from many tissues of $P$. trichocarpa downloaded from NCBI SRA database. A total of 164.8 million single-end clean reads were generated. The transcript abundance quantification using "kallisto" (Bray et al. 2016) showed that of all the 41,335 genes in the $P$. trichocarpa genome, over $29,000(70.2 \%)$ genes were expressed in $\mathrm{Qu}-2$ cells. Correlation analysis of gene expression patterns between $\mathrm{Qu}-2$ cells and tissues of $P$. trichocarpa indicated that the gene expression patterns of our Qu-2 cells were different from those of other tissues (Ma et al. 2019), especially in leaves, vessels and fibers (Fig. 5). However, patterns of our Qu-2

$\begin{array}{lccc}\text { Sample } & \text { Qu-2 cells r1 } & \text { Qu-2 cells r2 } & \\ \text { Qu-2 cells r1 } & 1.00 & 0.97 & \\ \text { Qu-2 cells r2 } & 0.97 & 1.00 & \\ \text { Pt phloem r1 } & 0.38 & 0.34 & \\ \text { Pt phloem r2 } & 0.39 & 0.37 & \\ \text { Pt shoot r1 } & 0.28 & 0.25 & \\ \text { Pt shoot r2 } & 0.36 & 0.32 & \\ \text { Pt xylem r1 } & 0.24 & 0.22 & \\ \text { Pt xylem r2 } & 0.29 & 0.26 & \\ \text { Pt root } r 1 & 0.18 & 0.18 & \\ \text { Pt root r2 } & 0.20 & 0.19 & \text { bar } \\ \text { Pt fiber r1 } & 0.16 & 0.16 & 1.00 \\ \text { Pt fiber r2 } & 0.19 & 0.19 & 0.80 \\ \text { Pt vessel r1 } & 0.13 & 0.13 & 0.60 \\ \text { Pt vessel r2 } & 0.15 & 0.14 & 0.40 \\ \text { Pt leaf r1 } & 0.07 & 0.06 & 0.20 \\ \text { Pt leaf } r 2 & 0.09 & 0.08 & 0.00\end{array}$

Fig. 5 Correlation of gene expression patterns between Qu-2 cells and other samples. Qu-2 cells: Qu-2 cells; phloem: phloem; shoot: shoot tip; xylem: stem differentiating xylem; root: primary root; fiber: fiber; vessel: vessel; leaf: leaf; $r 1$ and r2: biological replicate 1 and biological replicate 2

cells showed higher similarity to phloem and shoot than those of other tissues.

\section{Discussion}

Plant suspension cell lines have provided great convenience for molecular biological research. Among the established plant cell lines, tobacco BY-2 cell line is the most widely used. The Qu-2 cell line could be a better choice as a model system for woody plant research. The Qu-2 cell line has been maintained in our lab for six years, and didn't show any obvious change in culture characteristics. Qu-2 cells were well adapted to many known plant tissue culture media, such as MS, WPM, B5 and MH. A very unique characteristic of the $\mathrm{Qu}-2$ cells is that they can grow very well without adding any hormones in the culture media. We also established a cryopreservation and reaction procedure for the $\mathrm{Qu}-2$ cell line. The Qu- 2 cells can be kept between 4 and $8{ }^{\circ} \mathrm{C}$ for more than two months without losing the activity. The growth, maintenance, preservation of the Qu-2 cell line can be readily established in any plant biology labs.

Another unique characteristic of the Qu-2 cells is that they have a very high growth rate. The tobacco BY-2 cells can multiply by $80-100$ times within one week under appropriate growth conditions (Nagata et al. 1992), whereas the Qu-2 cells could increase more than 150 times in the same period of time. The most amazing feature of the Qu-2 cells 
is that their growth is not sensitive to cell density. Under liquid culture condition, most plant cells will stop growing when cell density reaches to a certain degree. However, the Qu-2 cells would not stop growing under liquid culture condition until the cells could not be shaken in an orbital incubator due to high medium consistency. Therefore, $\mathrm{Qu}-2$ cells could grow indefinitely. These unique traits indicated that the Qu-2 cells may be mass-produced in bioreactor for industrial applications.

We performed a series of tests to show that Qu-2 cells could be used as a convenient tool in plant biology research. Because of the thick cell walls, protoplasts are difficult to be generated from woody cells for transient transformation, RNA-seq, ChIP-seq and other experiments. Our results indicated the Qu- 2 cell line is a very effective source for protoplast isolation. In addition, the Qu-2 cell line can be used for both PEG-mediated and Agrobacterium-mediated transient transformation.

Approximately 29,000 genes were identified from the $\mathrm{Qu}-2$ cells by transcriptome analysis, which accounts for $70.2 \%$ of the genes in the P. trichocarpa genome. Unlike the BY-2 cells, Qu-2 cells produced chloroplasts and showed normal green on solid medium under light culture condition. They could be regenerated to whole shoots, implying that the Qu-2 cell is genetically totipotent in plant development. Therefore, the Qu-2 cells can be representative for gene function in whole plants.

Finally, we are willing to share our Qu-2 cell line with whoever wants to utilize the cell line for further research.

Open Access This article is licensed under a Creative Commons Attribution 4.0 International License, which permits use, sharing, adaptation, distribution and reproduction in any medium or format, as long as you give appropriate credit to the original author(s) and the source, provide a link to the Creative Commons licence, and indicate if changes were made. The images or other third party material in this article are included in the article's Creative Commons licence, unless indicated otherwise in a credit line to the material. If material is not included in the article's Creative Commons licence and your intended use is not permitted by statutory regulation or exceeds the permitted use, you will need to obtain permission directly from the copyright holder. To view a copy of this licence, visit http://creativecommons.org/licenses/by/4.0/.

\section{References}

Bae EK, Lee H, Lee JS, Noh EW, Choi YI, Lee BH, Choi DW (2012) Microarray and suppression subtractive hybridization analyses of gene expression in hybrid poplar (Populus alba $\times$ Populus tremula var. glandulosa) cell suspension cultures after exposure to $\mathrm{NaCl}$. Plant Physiol Biochem 58:151-158

Banu MNA, Hoque MA, Watanabe-Sugimoto M, Matsuoka K, Nakamura Y, Shimoishi Y, Murata Y (2009) Proline and glycinebetaine induce antioxidant defense gene expression and suppress cell death in cultured tobacco cells under salt stress. J Plant Physiol 166(2):146-156
Beyrne CC, Gonzalez RM, Iusem ND (2019) Strategy for the analysis of tissue-specific methylation changes without physical isolation. Epigenetics 14(1):41-51

Bray NL, Pimentel H, Melsted P, Pachter L (2016) Near-optimal probabilistic RNA-seq quantification. Nat Biotechnol 34(5):525-527

Chen H, Wang JP, Liu H, Li H, Lin YJ, Shi R, Yang C, Gao J, Zhou C, Li Q, Sederoff RR, Li W, Chiang VL (2019) Hierarchical transcription factor and chromatin binding network for wood formation in Populus trichocarpa. Plant Cell 31(3):602-626

Delporte A, De Zaeytijd J, De Storme N, Azmi A, Geelen D, Smagghe G, Guisez Y, Van Damme EJ (2014) Cell cycle-dependent O-GlcNAc modification of tobacco histones and their interaction with the tobacco lectin. Plant Physiol Biochem 83:151-158

Gai YP, Ji XL, Lu W, Han XJ, Yang GD, Zheng CC (2011) A novel late embryogenesis abundant like protein associated with chilling stress in Nicotiana tabacum cv. bright yellow-2 cell suspension culture. Mol Cell Proteomics 10(11):76-86

Han JY, Wang HY, Choi YE (2014) Production of dammarenediolII triterpene in a cell suspension culture of transgenic tobacco. Plant Cell Rep 33(2):225-233

Harashima H, Kato K, Shinmyo A, Sekine M (2007) Auxin is required for the assembly of A-type cyclin-dependent kinase complexes in tobacco cell suspension culture. J Plant Physiol 164(9):1103-1112

Issawi M, Muhieddine M, Girard C, Sol V, Riou C (2017) Unexpected features of exponentially growing Tobacco Bright Yellow-2 cell suspension culture in relation to excreted extracellular polysaccharides and cell wall composition. Glycoconj J 34(5):585-590

Jefferson RA, Burgess SM, Hirsh D (1986) beta-Glucuronidase from Escherichia coli as a gene-fusion marker. Proc Natl Acad Sci U S A 83(22):8447-8451

Krystofova O, Sochor J, Zitka O, Babula P, Kudrle V, Adam V, Kizek R (2013) Effect of magnetic nanoparticles on tobacco BY-2 cell suspension culture. Int J Environ Res Public Health 10(1):47-71

Lattanzio V, Caretto S, Linsalata V, Colella G, Mita G (2018) Signal transduction in artichoke [Cynara cardunculus L. subsp. scolymus (L.) Hayek] callus and cell suspension cultures under nutritional stress. Plant Physiol Biochem 127:97-103

Lin YC, Li W, Chen H, Li Q, Sun YH, Shi R, Lin CY, Wang JP, Chen HC, Chuang L, Qu GZ, Sederoff RR, Chiang VL (2014) A simple improved-throughput xylem protoplast system for studying wood formation. Nat Protoc 9(9):2194-2205

Ma Q, Bucking H, Hernandez JLG, Subramanian S (2019) Single-cell RNA sequencing of plant-associated bacterial communities. Front Microbiol 10:2452

Murashige T, Skoog F (1962) A revised medium for rapid growth and bio assays with tobacco tissue cultures. Physiol Plant 15(3):473-497

Nagata T, Nemoto Y, Hasezawa S (1992) Tobacco BY-2 cell line as the "HeLa" cell in the cell biology of higher plants. Int Rev Cytol 132:1-30

Nagata T, Sakamoto K, Shimizu T (2004) Tobacco by-2 cells: the present and beyond. Vitro Cell Dev Biol Plant 40(2):163-166

Niczyj M, Champagne A, Alam I, Nader J, Boutry M (2016) Expression of a constitutively activated plasma membrane $\mathrm{H}^{+}$-ATPase in Nicotiana tabacum BY-2 cells results in cell expansion. Planta 244(5):1109-1124

Ohlsson AB, Djerbi S, Winzell A, Bessueille L, Ståldal V, Li X, Blomqvist K, Bulone V, Teeri TT, Berglund T (2006) Cell suspension cultures of Populus tremula $\times$ P. tremuloides exhibit a high level of cellulose synthase gene expression that coincides with increased in vitro cellulose synthase activity. Protoplasma 228(4):221-229

Ohmiya Y, Takeda T, Nakamura S, Sakai F, Hayashi T (1995) Purification and properties of a wall-bound endo-1,4- $\beta$-Glucanase 
from suspension-cultured poplar cells. Plant Cell Physiol 36(4):607-614

Ozawa K, Komamine A (1989) Establishment of a system of highfrequency embryogenesis from long-term cell suspension cultures of rice (OrQu-2a sativa L.). Theor Appl Genet 77(2):205-211

Park Y, Son SH (1988) Regeneration of plantlets from cell suspension culture derived callus of white poplar (Populus alba L.). Plant Cell Rep 7(7):567-570

Rao X, Shen H, Pattathil S, Hahn MG, Gelineo-Albersheim I, Mohnen D, Pu Y, Ragauskas AJ, Chen X, Chen F, Dixon RA (2017) Dynamic changes in transcriptome and cell wall composition underlying brassinosteroid-mediated lignification of switchgrass suspension cells. Biotechnol Biofuels 10(1):266

Scherer WF, Syverton JT, Gey GO (1953) Studies on the propagation in vitro of poliomyelitis viruses. IV. Viral multiplication in a stable strain of human malignant epithelial cells (strain HeLa) derived from an epidermoid carcinoma of the cervix. J Exp Med 97(5):695-710

Shi R, Wang JP, Lin YC, Li Q, Sun YH, Chen H, Sederoff RR, Chiang VL (2017) Tissue and cell-type co-expression networks of transcription factors and wood component genes in Populus trichocarpa. Planta 245(5):927-938

Toussaint F, Pierman B, Bertin A, Lévy D, Boutry M (2017) Purification and biochemical characterization of NpABCG5/NpPDR5, a plant pleiotropic drug resistance transporter expressed in Nicotiana tabacum BY-2 suspension cells. Biochem J 474(10):1689-1703

Tuskan GA, Difazio SP, Jansson S, Bohlmann J, Grigoriev IV, Hellsten U, Putnam NH, Ralph SG, Rombauts S, Salamov A, Schein J, Sterck L, Aerts A, Bhalerao RR, Bhalerao RP, Blaudez D, Boerjan W, Brun A, Brunner A, Busov V, Campbell M, Carlson J, Chalot
M, Chapman J, Chen GL, Cooper D, Coutinho PM, Couturier J, Covert S, Cronk Q, Cunningham R, Davis J, Degroeve S, Déjardin A, Depamphilis C, Detter J, Dirks B, Dubchak I, Duplessis S, Ehlting J, Ellis B, Gendler K, Goodstein D, Gribskov M, Grimwood J, Groover A, Gunter L, Hamberger B, Heinze B, Helariutta Y, Henrissat B, Holligan D, Holt R, Huang W, Islam-Faridi N, Jones S, Jones-Rhoades M, Jorgensen R, Joshi C, Kangasjärvi J, Karlsson J, Kelleher C, Kirkpatrick R, Kirst M, Kohler A, Kalluri U, Larimer F, Leebens-Mack J, Leplé JC, Locascio P, Lou Y, Lucas S, Martin F, Montanini B, Napoli C, Nelson DR, Nelson C, Nieminen K, Nilsson O, Pereda V, Peter G, Philippe R, Pilate G, Poliakov A, Razumovskaya J, Richardson P, Rinaldi C, Ritland K, Rouzé P, Ryaboy D, Schmutz J, Schrader J, Segerman B, Shin H, Siddiqui A, Sterky F, Terry A, Tsai CJ, Uberbacher E, Unneberg P, Vahala J, Wall K, Wessler S, Yang G, Yin T, Douglas C, Marra M, Sandberg G, Van de Peer Y, Rokhsar D (2006) The genome of black cottonwood, Populus trichocarpa (Torr. \& Gray). Science 313(5793):1596-1604

Wang Z, Zhu T, Ma W, Fan E, Lu N, Ouyang F, Wang N, Yang G, Kong L, Qu G, Zhang S, Wang J (2020) Potential function of CbuSPL and gene encoding its interacting protein during flowering in Catalpa bungei. BMC Plant Biol 20(1):105

Yu M, Yuan M, Ren H (2006) Visualization of actin cytoskeletal dynamics during the cell cycle in tobacco (Nicotiana tabacum $\mathrm{L}$. cv Bright Yellow) cells. Biol Cell 98(5):295-306

Publisher's Note Springer Nature remains neutral with regard to jurisdictional claims in published maps and institutional affiliations. 